\title{
Local authority provision of environmental planning guidelines for event management in Ireland
}

\author{
James Hanrahan $^{1}$ and Kelly Maguire ${ }^{2 *}$
}

Received: 25/04/2015 Accepted: 03/11/2015

\footnotetext{
${ }^{1}$ School of Business and Social Sciences Department of Marketing, Tourism and Sport, Institute of Technology Sligo, Ireland

2 School of Business and Social Sciences, Department of Marketing, Tourism and Sport, Institute of Technology, Sligo, Ash Lane, Ballinode road, Sligo, Ireland; phone: +353 879155226; e-mail: kelly.maguire@mail.itsligo.ie

* Corresponding author
}

\begin{abstract}
This paper discusses the environmental impacts generated by hosting events. More specifically it focuses on the case study of assessing the provision of environmental planning guidelines by Local Authorities to manage the environmental impacts of events in Ireland. In order to determine which Local Authorities provided environmental planning guidelines, a quantitative methodology in the form of a content analysis approach was utilised to investigate every Local Authority in the Republic of Ireland. Analysis has revealed that few Local Authorities are providing planning guidelines for event management, which focus on environmental concerns. As such, the realization of the need to provide environmental planning guidelines to manage the environmental impacts of event management within Local Authorities has not been recognised nationwide. As a result the need for coherent guidelines and policies with sustainable indicators within Local Authorities is vital to further develop, grow and advance the event sector in Ireland. This paper concludes that while the low levels of environmental sustainability in Local Authorities for event management is worrying; it offers an opportunity to be improved by adopting and utilising best practice indicators in environmental policies and guidelines for event management.
\end{abstract}

(C) 2016 Varna University of Management. All rights reserved

Keywords: Event Planning, Event Management, Environmental Planning, Guidelines, Ireland, Local Authorities

Citation: Hanrahan, J., K. Maguire (2016) Local authority provision of environmental planning guidelines for event management in Ireland. European Journal of Tourism Research 12, pp. 54-81

\section{Introduction}

The event industry on a global scale can contribute both positively and negatively to the economy, society and the environment. This paper reports on the environmental consequences of events at an international level while focusing also on the environmental consequences of this large-scale event study in 
Ireland. It reports on the role Local Authorities play in planning for the environmental sustainability of events. The findings from this paper are discussed in the context of national legislation to provide an insight on the environmental sustainability of Local Authority planning provision for event management in the case of Ireland. Local Authorities play a crucial role as policy makers in planning for event licensing and providing event guidelines for a sustainable event industry. Planning for environmental sustainability in event management has become vital in determining and mitigating the negative consequences created by activities generated at events. As such, the use of sustainable planning tools is necessary now more than ever before since events worldwide are growing at an expedient rate (Janeczko, Mules \& Ritchie, 2002; Getz, 2008; Jones, 2008; Quinn, 2009; Raj \& Musgrave, 2009; Bowdin, Allen, Harris, McDonnell \& O'Toole, 2012). As a result of this, events are now a valuable counterpart of the tourism industry. On a global scale there are 56 million regularly occurring festivals and events held throughout the world each year. As such, the popularity of the event industry is estimated to have an economic impact that reaches more than $\$ 1$ trillion (International Festival and Event Association, 2009). For this reason, events have become an important motivator of tourism and now figure prominently in the development and marketing plans of most destinations (Getz, 1997; Getz, 2008; Cibinskiene, 2012; Quinn, 2013). However, experience has shown that events generate both positive and negative impacts on society, the economy and the environment (Janeczko et al, 2002; Fredaline, et al, 2003; Gursoy et al, 2004; Robinson et al, 2011; Wambach et al, 2015). Specifically, the implications caused to the environment as a result of hosting an event cause long-term extensive damage and degradation (Jones, 2008; Maguire, 2013) and are a significant cause for concern. In fact they cause inevitable modifications to the environment (Wall \& Mathieson, 2006). As a result the need for coherent guidelines and policies with sustainable indicators within Local Authorities is vital to further develop, grow and advance the event sector both nationally and internationally.
In particular, it has been noted globally that the complicated relationship between events and the environment (Shone \& Parry, 2004; Jones, 2010) has been initiated by the vast generation of negative impacts produced by events (Raj \& Musgrave, 2009; Hamil et al, 2012; Case, 2013). These impacts can impose a significant environmental cost for host localities, host organisations and Local Authorities (Jones et al, 2008; Omoregie, 2012). Notably, they are caused as a result of requiring great amounts of resources such as water and energy (Shanka \& Alamiyo, 2004; Grames \& Vitcenda, 2012). This effectively impacts the sustainability of the event. For this reason, the need to plan for event impacts is crucial and cannot be underestimated (Raj \& Musgrave, 2009). Consequently it has been noted worldwide that not managing these negative outcomes can result in excessive resource use, consumption, ecological degradation, pollution, waste generation, and traffic congestion, (Jones, 2008; Omoregie, 2012) to mention a few. As a result, the requirement of planning for events and its associated environmental impacts has become a focal point for Local Authority planners at a global scale in recent years. Moreover the requirement of providing environmental planning guidelines is a necessity. However they are often unavailable within Local Authorities. Hence the need to identify the provision of Local Authority planning tools and guidelines used to assess environmental priorities in Local Authorities for event management, with a particular focus on Local Authority planning provisions in Ireland.

Local Authorities are central to the organisation and authorisation of events on a global scale. They play a key role in the planning processes of regulating events (Bowdin et al, 2006; Wood, 2009; Bowdin et al, 2012; Bladen, Kennell, Abson \& Wilde, 2012; IRO, 2013). On an international level, it is in the Local Authority remit to provide supporting conditions for obtaining and operating temporary event licenses within the Local Authority jurisdiction (Raj et al, 2009). As such, licensing events seems to be a legal requirement of Local Authorities to ensure that events are organised and conducted in a manner that is safe for event audiences (Wood, 2006; Government of Western Australia, 2009; Van der Wagen \& 
White, 2010; NSW Government, 2011; Department of the Environment, Community and Local Government, 2010), which include event stakeholders, performers and event attendees (Department of the Environment Community and Local Government, 2014). In conjunction with this, Local Authorities play a role in ensuring events are conducted in a way that is environmentally sustainable, causing minimal harm to the environment (Bowdin et al, 2010; NSW Government, 2011; UNEP, 2012; Department of the Environment, Community and Local Government, 2014). However, the generation of risks and unavoidable impacts especially to the environment are inevitable at all events (Jeong \& Faulkner, 1996; Fredaline et al, 2003; Gursoy et al, 2004; O'Brien \& Gardiner, 2006) regardless of the event size or scale (Omoregie, 2012). It has been noted that in Ireland, at a national level, under Irish legislation, obtaining and operating event licenses is determined purely by crowd size whereby an audience comprises of 5000 people or more (HSE, 2014). In essence, it seems Local Authority policy makers worldwide are in an ideal position to plan for and provide more sustainable management tools such as guidelines and policies to facilitate sustainable environmental planning for event management.

This paper presents a contribution to knowledge as the case study provides a current state of environmental planning by Local Authorities for event management with a particular focus on Ireland. It outlines the need for development solutions to be provided by Local Authorities at an international and national level to deal with the environmental impacts of event management. It is an up to date assessment of Local Authority planning provision for event management in Ireland, which facilitates an opportunity for further longitudinal study in the area.

\section{Literature Review}

The environmental impacts created as a result of hosting an event have been well documented in event management research worldwide (Hall, 1992; Fredaline, Jago \& Deery, 2003; Jones, 2008; Collins et al, 2009; Jones, 2010; Van der Wagen, 2010; Omoregie, 2012; UNEP, 2012; Dashper, 2015) and has been at the core of several theoretical discussions (Gossling \& Hall, 2006; Kaval, 2011; Collins et al, 2009; Jones, 2012; Case, 2013; Yeoman et al, 2015; Holmes et al, 2015). However little information has been documented in relation to how host organisations such as Local Authorities plan for the environmental impacts of events. Similarly it has become visually evident from event management that activities from hosting an event cause extreme consequences for the environment (Getz, 1997; Fredaline et al, 2003; Kim et al, 2006; Gursoy \& Kendall, 2006; Collins et al, 2009; Jones, 2010; Case, 2012; Yeoman et al, 2015). Specifically the areas of waste, water, air, transport, food and energy can effectively impact the use of resources, cause pollution and land degradation, contribute to carbon emissions and drastically affect the longevity and quality of the event (Raj \& Musgrave, 2009; David, 2009; Jones, 2010) as well as the quality and health of the environment. Consequently, not managing such impacts of events can compromise sustainability (Shipway \& Fyall, 2012) on a global scale. For this reason, there is a pressing need to manage the environmental impacts of events within a sustainability framework (Stone \& Sharpley, 2011). As a result, the need for an environmental planning approach to mitigate such impacts is essential in facilitating and regulating environmental sustainability in event management worldwide. Likewise an environmental planning approach coordinated by Local Authorities can effectively facilitate the process of achievement for environmental sustainability in event management (Vernon et al, 2005; DECLG, 2011). Thus, giving Local Authorities the power to control and manage this planning process through the provision of sustainable environmental planning policies and guidelines. This is turn can determine the degree of planning needed to mitigate environmental impacts of events.

A further detailed investigation into event impacts highlighted the importance of planning for environmental sustainability to manage event impacts. Specifically, resource consumption taking into consideration energy and water consumption, water quality, wastewater and sewage treatment are essential aspects necessary in planning for 
environmental sustainability of event management (Omer, 2008; Raj \& Musgrave, 2009; Jones, 2010; Jones, 2014). Energy consumption at festivals and events from electricity and heating demands generate increased energy emissions (Jones, 2010; Saayman, 2012). Despite this, the use of energy at events is required to operate accommodation facilities, cooking requirements, stage operations, transport and travelling and operating entertainment devices (Raj \& Musgrave, 2009). All of which can have a negative $\mathrm{co} 2$ and greenhouse gas effect on populations (Jones, 2014) at a global and local scale. However adopting energy efficient measures when hosting events such as Peats Ridge Festival in Australia, where 100\% renewable energy is utilised (Peats Ridge Festival, 2014), can facilitate a transition towards environmental energy conservation. Subsequently water consumption on the other hand is used in excess at events, which has been noted to contribute to the ever-shrinking freshwater resources (Raj \& Musgrave, 2009; Gossling, Peeters, Hall, Ceron, Dubois, Lehmann \& Scott, 2011). However water is an incremental provision at events as it is used for personal hygiene, sanitation and food preparation (Jones, 2014). In fact, it is a prerequisite at festivals and events to provide drinking water stations for event attendees (Jones, 2010). This in turn can contribute to excess resource consumption. As well as this, the provision of drinking water stations requires water quality to be monitored and maintained (Robertson et al., 2003; EPA, 2012). As such, a water conservation management and monitoring approach is essential to manage over consumption (World Health Organisation, 2004; World Health Organisation, 2013). Thus, implementing a water conservation approach similar to Boom Festival in Portugal, where in 2012, water consumption was reduced to $5.3 \mathrm{~m}$ litres in comparison to $13.5 \mathrm{~m}$ litres being consumed in 2008, could aid the responsible management of water preservation. In conjunction with this, the necessity of using water at events inevitably produces wastewater (Jones, 2010). Consequently wastewater can make its way back into groundwater therefore causing pollution of ecosystems (UNEP, 2011), which is a primary environmental concern and therefore warrants management.
Similarly, sewage treatment is also a major concern, which consumes energy and produces large quantities of emissions (Wale, Robinson \& Dickson, 2010; Bowdin et al, 2012; Case, 2013). However energy in the form of electricity is needed for sewage treatments therefore impacting the environment (Jones, 2014). Likewise the mismanagement of sewage to soil, natural habitats and water systems can create pollution if leakages occur as well as release toxins into the air (Raj \& Musgrave, 2009; Wale, Robinson \& Dickson, 2010; Finkel, McGillivray \& McPherson, 2013). However a water treatment station was implemented at the Rock Werchter festival in Belgium collecting sanitary and other waste during the festival, which is then filtered and infiltrated (Rock Werchter, 2015). Thus adopting a wastewater and sewage treatment management approach can contribute to the minimization of resource consumption and the prevention of pollution. Another environmental consequence of events is waste generation, which is inevitable at events and produces both visual and physical impacts, which can be detrimental and irreversible (Raj \& Musgrave, 2009; David, 2009). Crucially, it can damage the geological environment with un-removed rubbish releasing toxic materials into soil, vegetation and flora and fauna (Raj \& Musgrave, 2009). Also waste mismanagement from leftover food and beverage consumption can deplete natural resources as well as contribute to air, water and soil pollution (Raj \& Musgrave, 2009; Van der Wagen, 2010). Accordingly the abandoned tents left behind at festivals contribute to waste generation (A Greener Festival, 2012). This affects the environmental landscape around the area of interference and disturbance of the natural habitat (Ali-Knight, Fyall, Robertson \& Ladkin, 2009). For example, in 2011 , over 12,000 tents were left behind at the Isle of Wight festival, UK, which contributed to extensive environmental damage (Moore, 2014). However the development of tent management initiatives can aid in the management of this issue and promote sustainable solutions for tent management. Therefore the need to maximize the recycling of waste and minimise landfill is critical in event management. However adopting waste management best practice similar to Germany, where a ban on 
non-treated wastes to landfill has been implemented since 1993; a ban on combustible waste to landfill since 2011 and no landfilling after 2015 (Fischer, 2013) can be beneficial to various countries if applied and implemented at a global level.

Correspondingly, overcrowding and congestion at festivals and events is not only a health and safety issue (Goldblatt, 2010) as seen at the Love parade Germany 2010 where overcrowding caused 21 deaths and left over 500 people injured (The Guardian, 2010; BBC News, 2010). It also has environmental threats, such as a direct detrimental effect on land degradation (UNCCD, 2014), which was highlighted by the Mendip District Council upon hosting Glastonbury Festival in the UK in 2002. Additionally, transport greatly impacts the environment, as it is the largest $\mathrm{Co} 2$ contributor for events since transport delivers people, goods and operational equipment to events (Davenport \& Switalski, 2006; Sorupia, 2005; Raj \& Musgrave, 2009). This releases toxic emissions resulting in air pollution on a global scale (EPA, 2014) and noise pollution (Richards \& Palmer, 2010; Yeoman, Robertson, Ali-Knight, Drummond, McMahonBeattie, 2004; Carlsen, 2004; Small, Edwards \& Sheridan, 2005; Case, 2013) at a local level. Similarly, catering stalls produce waste and contribute to soil and water pollution (Jones, 2010; Jones, 2014). However by adopting principles similar to Roskilde festival in Denmark where organic and local food producers are sourced and eco friendly food packaging is utilised, negative environmental consequences can be minimised (Roskilde Environmental Group, 2014). Furthermore pollution in air and water can be caused by events since they produce co2 emissions and greenhouse gases from the mismanagement of transport, accommodation and catering facilities, operating entertainment facilities, sewage and sanitary facilities, and waste facilities (Roper, 2006; UNWTO \& Ministry of Tourism and Environment, 2007; David, 2009; Raj \& Musgrave, 2009; Getz, 2009; Robinson, Wale \& Dickson, 2010; Laing \& Frost, 2010; Goldblatt, 2012). Therefore the need for the implementation of mechanisms to reduce consumption, avoid pollution and manage environmental impacts cannot be underestimated and requires solutions to mitigate such impacts. However since the environment is one of the most basic resources for tourism and a core element of tourism products (Wall \& Mathieson 2006), a balanced approach to policy and guideline planning decision making for environmental considerations is needed. This is fundamental in planning to avoid irreversible event environmental damage.

Additionally, as a result of the increasing attention commanded by environmental impacts, Local Authorities around the developed world have a legal responsibility to ensure events are conducted in a way that is environmentally sustainable (NSW Government, 2011; UNEP, 2012; DECLG, 2014). This is essential now more than ever before around the world, since the event sector worldwide has become an extremely valuable industry accounting for more than $€ 1$ trillion in tourism revenue and attracting increased tourist arrivals around the globe on an annual basis (UNWTO, 2015). Therefore, due to the unparalleled growth of events worldwide, there is now a growing recognition of the importance of sustainability (Font \& Harris, 2004; Murphy \& Price, 2005; Weaver, 2006). On a national level, in the case of Ireland, planning sustainably for the environment is essential since Ireland's beautiful scenery has been identified as a key factor in a tourist's decision to visit Ireland (Tourism Ireland, 2010). As such, the protection and promotion of a high quality environment is of great importance (Damster \& Tassiopoulos, 2005; Mallen \& Adams, 2010, 2013; DECLG, 2012) and is fundamental for the sustainable development of events. For this reason, the importance of a holistic and consistent sustainable planning approach for events with a strong focus on the environment is required and cannot be underestimated. It can be achieved with the implementation of regulations for sustainable environmental planning policies and guidelines within Local Authorities worldwide and in the case of Ireland, nationwide. These sustainable environmental planning policies and guidelines can act as a tool to aid environmental planning in event management. It can also improve the overall environmental quality of a destination, 
which is essential in sustaining a tourism product.

Furthermore the connection between Local Authorities and events is significant on a universal scale. Local Authorities play a noteworthy role in the planning process of events and are central figures to the organisation and authorisation of events (NSW Government, 2011; Irish Regions Office, 2013). In terms of planning for the environment, Local Authorities internationally, around the developed world and nationally, in Ireland, provide licensing conditions that must be complied with to ensure that facilities are designed, built and operated in ways that minimise environmental harm (Goldblatt, 2010; NSW Government, 2011; DECLG, 2012). More specifically a precondition for licensing events requires the application process to include a draft environmental monitoring programme for before, during and after the proposed event (Raj \& Musgrave, 2009; DECLG, 2012; HSE, 2014). Therefore Local Authorities have the ability to enable sustainable development in events through planning. Similarly the incorporation of set environmental priorities for event planning in legislative compulsory development plans can facilitate the environmental sustainability of events. More specifically, the responsibility of ensuring the environment is maintained to the highest quality through planning and development falls to a number of departments within Local Authorities. This includes the fire department, planning department, building control and importantly the environmental services. These departments are responsible for a spectrum of services, all of which have an association with environmental planning for events (Government of Western Australia, 2009; Van der Wagen \& White, 2010; NSW Government, 2011; Department of the Environment, Community and Local Government, 2010). Their services include planning, building control, developing infrastructure, car parks, signage, roads, water supply and sewage, waste management, agriculture, health, welfare, recreation facilities and amenities and most importantly the environmental protection of an event location (DECLG, 2010). The management of these services is detrimental to the quality and health of the environment.
Therefore, Local Authority involvement in the environmental planning and management of events is essential in the development, growth and advancement of the industry. As such the provision of environmental policies and management procedures in Local Authorities worldwide can facilitate planning and development for a high quality environment which can contribute to a sustainably viable and responsible event industry (DEHLG, 2007). Additionally there are a range of planning and management solutions and methods to the problems and issues associated with environmental consequences. These regulatory instruments include an Environmental Impact Assessment (EIA), a Strategic Environmental Assessment (SEA), the UNWTO 12 aims of sustainable tourism, indicator systems such as the Global Sustainable Tourism Criteria, the European tourism indicator system and the DIT ACHIEV Model of sustainable tourism and event management as well as sustainable environmental guidelines and policies. The use of such regulatory policy instruments can be used to achieve desired levels of environmental protection and sustainability for event management around the globe. They can be applied to tourism destinations and tourism activities worldwide. Hence, the consideration of these tools in relation to sustainable environmental planning for event management by Local Authorities can facilitate successful environmental planning for event management and reduce or eliminate harmful environmental consequences. The following subsections are discussed in relation to Local Authority planning for event management. For the purpose of this research, these management tools were applied to the case of Ireland, where the authors assessed compliance of Local Authority planning provisions with such tools.

\section{Environmental Impact Assessment (EIA)}

Environmental Impact assessments (EIA's) have been carried out for years and adopted extensively worldwide ( $\mathrm{Li}, 2008$ ). In Ireland, the EIA directive was adopted over 25 years ago to reflect changes in EU legislation and policy. However this regulatory tool has recently been amended (2014/52/EU) and reentered into force in 2014 to simplify rules for assessing the potential effects of activities on the environment. EIA's have become a crucial 
factor in determining the level of environmental risk associated with events (OECD, 2003; Tassiopoulous, 2005; Raj \& Musgrave, 2009; Mallen \& Adams, 2013) and must be conducted prior to hosting an event. However, it has been noted that an environmental impact assessment should be conducted before, during and after an event (Ferdinand \& Kitchin, 2012; DECLG, 2013) to clearly illustrate the transitional damage throughout the event. This can effectively demonstrate the damage and environmental degradation caused as a result of hosting an event (Ritchie, 1984; Ritchie \& Smith, 1991; Hugo, 1996; Raj \& Musgrave, 2009; Xiao, 2014). Moreover it can improve the level of environmental protection with a view of enabling more sustainability in event management. As a result, the need to protect and provide a high quality environment is crucial since the environment is one of the key factors in a successful tourism industry (Griffin \& Carty, 2006; DTTAS, 2010; Tourism Ireland, 2014). However tourism and its associated counterparts such as the event industry cannot be sustained if the environmental resource base is degraded beyond its capacity (Green et al, 1992; Griffin \& Carty, 2006; Greenidge \& Greedidge, 2011). Therefore environmental impact assessments are of great importance not only to the environment but also to society. Thus, the need for Local Authorities to play a greater role in environmental protection for events cannot be underestimated.

In fact, it has been noted that governments throughout the world are increasingly using EIA's as a means of preparing for environmental consequences that can be caused by actions at events (Canter, 1999; Macintosh, 2010; Bisset, 2011; Evans, 2014). This has resulted in the EIA becoming a widely accepted tool in environmental management (Wathern, 2013). Subsequently, under the Planning and Development Act 2000 and 2010, guidelines and regulations outline the importance of ensuring the environmental quality of a destination. It also ensures that balanced decision-making occurs. Therefore decision makers involved in the development and licensing of events must authorize the conduct of the EIA. Hence environmental management coordinated through Local Authorities can play a pivotal role in generating positive returns for host organisations and can contribute to the sustainable development of events. In addition to this method, the strategic environmental assessment can also enable environmental sustainability in planning for events at a global scale.

\section{Strategic Environmental Assessment (SEA)}

The Strategic Environmental Assessment (SEA) is similar to the EIA in that they share the same objectives and solely relate to each other with the same policy and planning process (Lee \& Walsh, 2012). This proactive management approach has long been advocated in tourism planning since the 1990's (Lemos et al, 2012). Additionally both approaches are based on a principle where a preventative approach is utilised to facilitate environmental protection (Partidario, 2003; Abaza et al, 2004; González et al, 2011; DECLG, 2013). Moreover the SEA has become a mandatory requirement under the Planning and Development Act regulations 2004 and is now a legal requirement under Irish legislation (DECLG, 2015). In addition to this, it is a legal requirement of member states in the EU under the SEA Directive (2001/42EC) as set out by the European Commission in 2001 (EC, 2015). The primary objective of the SEA is to provide a high level of protection for the environment and to promote sustainable development by contributing to the integration of environmental considerations into the preparation and adoption of specified plans and programs (EC, 2005; Partadario, 2007; Spaziante \& Murano, 2008; DoEHLG, 2009). Furthermore policies, plans and programs in the SEA Directive must be prepared or adopted by an authority at national, regional or local level and be required by legislative, regulatory or administrative provisions (European Commission, 2015). Therefore it is the role of local governments globally to develop and integrate these policies into plans and strategies. For the case of Ireland, such policies should be integrated in what is known as County Development Plans (CDP's). County Development Plans are a legal requirement in Ireland under the Planning and Development Act, which outlines the objectives of the county for a 6-year period. Thus, like the tourism industry, the event industry should be taken into consideration in these policies and plans. Furthermore a 
strategic environmental assessment should be carried out for the event industry to contribute to the sustainable development of the country.

However, some would argue that the SEA is a more legitimate and comprehensive tool for environmental monitoring and management than the EIA for a number of reasons. For instance, a limitation of the EIA in contrast to the SEA is that the SEA sets a framework for future developments whereby under EU legislation, SEA member states must monitor the significant environmental effects of the implementation of plans and programs. Also EIAs are site specific and normally involve one activity and are therefore not strategic (Thrieval \& Partidario, 1996; Thrieval, 2012). Furthermore EIA's may occur too late in the planning process while SEA's can help to facilitate early consideration of the environment (Wood \& Dejoddour, 1992; Scott, 2008; Cornish, 2013; Jones et al, 2013) therefore helping to alleviate negative impacts. As a result, SEA may make EIA redundant if impacts have been examined sufficiently at the planning stage. Yet, both approaches can be adopted and utilised as a tool for facilitating and maximizing environmental sustainability for event planning by Local Authorities not only in Ireland but also at an international level.

\section{Sustainable Indicators}

Sustainable indicators have become a popular tool for measuring and monitoring the sustainable development of tourism related activities. The use of indicators for monitoring progress towards sustainability has been advocated and discussed by tourism researchers, policy makers and tourism organisations over many years (Miller, 2001; Ceron and Dubois, 2003; UNWTO, 2004; Miller and Twining-Ward, 2005; Choi and Sirakaya, 2006; Hyde et al, 2007; Griffin, 2007; Mowforth \& Munt, 2009; Morrissey et al, 2010; EC, 2013). In fact the United Nations World Tourism Organisation has been promoting the use of sustainable tourism indicators since the early 1990's as essential instruments for policy making planning and management procedures for destinations. As a result, indicators have become the main recognised evaluation tool used to support sustainable tourism policy implementation (Choi \& Sirakaya, 2006;
Tanguay et al, 2011; Rajaonson \& Tanguay, 2012). Thus having established that events are an important sector of the Irish economy, it is important to improve its development in a sustainable manner to ensure the long-term success of the industry. Therefore adopting and utilising indicators in policy making for the development of plans and guidelines worldwide, for event management can facilitate the environmental sustainability of events.

In the context of sustainable tourism development, indicators are defined as "information sets, which are formally selected for regular use to measure changes in assets and issues that are key for the tourism development and management of a given destination" (UNWTO, 2004). Measuring and monitoring sustainable tourism development processes can enable stakeholders to benchmark their progress and performance in the future. As such sustainable tourism is now being consolidated at an international level with a focus on making all types of tourism more environmentally beneficial (Lozano-Oyola et al, 2012), since the tourism sectors competitiveness is closely linked to its sustainability. For this reason, the impact of tourism and its counterparts such as events must be monitored closely because of its direct and indirect impacts on the environment. Thus adequate planning is required to safeguard against potential negative impacts.

Additionally, managing the process of sustainable development is essential to create the right balance between the needs of tourists, host communities and the environment (UNEP, 2005; Muhanna, 2006; Holden, 2008). Given the negative impacts generated at events, development must follow a path that is sustainable and maximises benefits while minimising the impact on the physical and human environment (Tanguay, et al, 2011). Also the UNWTO (2004) indicated that the sustainable development of tourism and its counterparts should promote the optimal use of resources. Therefore managing event impacts in a sustainable manner can ensure that capacities and limits to resource use is recognised, therefore ensuring environmental sustainability of the event industry. 
Furthermore, the usefulness of indicators for measuring progress, can also stimulate a learning process to enhance the overall understanding of environmental and social problems, facilitate community capacity building and help in identifying sustainable development goals and suitable management strategies (Miller and Twining-Ward, 2005; Reed et al, 2006). Therefore indicators have been promoted as useful, reliable and as an easily comprehensible assessment and communication tools for decision makers (OECD, 2003; UNWTO, 2004). For this reason, the integration of sustainable indicators in environmental polices for event management by Local Authorities is needed. Hence, Local Authorities at an international level and at a national level in Ireland can benefit from adopting and utilising sustainable indicators in identifying potential impacts event activities can have on the environment. As such sustainable indicators have been integrated into the content analysis tool to assess their adoption and integration within Local Authority environmental planning guidelines and policies for event management in Ireland (Table 4). These indicator systems can be applied to assess international and national environmental planning guidelines and processes for event management. Notably, there are international and national indicator sets available for contributing to the sustainable development of tourism and events. These include the DIT ACHIEV Model (2007), Global Sustainable Tourism Criteria (2013) and the European Tourism Indicator System (2013). In addition to this, there are also the 12 aims of sustainable tourism, which can be applied to tourism activities such as events. This tool is also incorporated within the content analysis tool to assess Local Authority compliance with this tool within planning processes and provisions.

Sustainability is imperative in all of these management systems. The 12 aims of sustainable tourism are a set of aims used in tourism planning, management and monitoring processes which provide accurate results for decision making (WTO \& Ministry of Tourism and Environment, 2007). They can be formulated and used in frameworks to develop policies for more sustainable tourism. These aims are based around two principles. Firstly, it minimises the negative impacts on society, the economy and the environment. Secondly it maximises tourism positive contributions to local economies and the conservation of natural and cultural heritage as well as the quality of life of hosts and visitors. The Global Sustainable Tourism Criteria is a tool for managing sustainability in tourism. It strives to achieve best practice in sustainable tourism and fosters sustainable tourism through the adoption of universal sustainable tourism principles. The indicators from all these tools are guiding principles for measuring and monitoring sustainability, which offers an opportunity to reduce and mitigate negative consequences, which may occur. The European Tourism Indicator System also measures performance and monitors results while enhancing sustainability performance (EC, 2014; EC, 2015). It can be beneficial to Local Authorities in getting improved data for informed policy decision making and establishing an intelligent approach to tourism planning. It also identifies areas for improvements and managing risks effectively. The DIT ACHIEV model (a tool for sustainable event management) is a management system developed for an Irish context. This model focuses on environmental integrated management, which in the context of Event management is significant in aiding environmental sustainability. The DIT ACHIEV model recognises that the tourism industry and its counterparts are an important source of revenue, investment and employment throughout Ireland. Therefore the use of sustainable aims and indicators applied in an event management context is critical for the sustainability of the event industry. Significantly all four management systems offer an opportunity to measure, monitor and facilitate sustainability in tourism products and resources and can be applied to aid sustainability in event management.

\section{Guidelines and Policies}

Having identified Irelands unspoilt environment as a key factor for consideration in choosing Ireland as a destination (Fáilte Ireland, 2014), it is necessary to maintain and protect its quality to ensure its longevity. To do this, it is necessary that sustainable environmental guidelines and policies be developed to 
safeguard the viability of the environment against degradation and damage created by negative tourism activities such as events. Environmental guidelines and policies can facilitate responsibility in planning processes taking into consideration environmental concerns. This in turn creates good practice in environmental sustainability, which is crucial for event planning and management. In the context of planning for event management, numerous guidelines have been developed by experts to aid planners in developing environmentally sustainable tourism (McLaughlin \& Hanrahan, 2015). However more guidelines exist for aiding environmental sustainability in tourism in contrast to events. Though, it is important to note that no legislative guidelines for ensuring environmental responsibility in event management have been produced in Ireland. Conversely on further examination, limited environmental planning guidelines exist internationally within local governments specifically for event management. Yet the New South Wales Government in Australia (NSW Government, 2011) produced guidelines to assist councils in developing event management policies. Nevertheless, there appears to be a lack of specific environmental event planning guidelines. This calls for improvements in the development of more environmentally sustainable planning processes for event management worldwide.

The authors of this paper have produced basic environmental planning guidelines, which may be adopted, implemented, and utilised by Local Authorities at a global or national level, in Ireland, to manage the environmental impacts of festivals and events. These guidelines can be viewed below in Table 1 .

Considering Local Authorities have an important role to play as environmental protection authorities and agents for sustainable development, the adoption of such guidelines can aid the transition towards environmental sustainable development. Importantly these guidelines are devised from international literature and are compliant with international best practice standards such as the UNWTO/UNEP 12 aims of sustainable tourism (2005), the Global Sustainable Tourism
Criteria (2013), the European Tourism Indicator System (2013) and the DIT ACHIEV Model of sustainable event management (2007). It also incorporated guidelines as set out by the Department for the Environment, Food and Rural Affairs, UK (2007) and Failte Ireland (the National Tourism Development Authority of Ireland) best practice guidelines (2007) and guidelines for environmental good practice (2012). The implementation of such environmental guidelines and environmental policies within Local Authorities for event planning and management is key to its sustainable development and the longevity of a responsible and sustainable event industry. This cannot be underestimated having identified the environmental impacts caused as a result of events. As such, the need for the development and implementation of Local Authority sustainable environmental planning policies and guidelines for event management is needed within relevant legislation to ensure a sustainable event planning process. In particular the provision of environmental planning guidelines (below) and policies for environmental considerations of event management is critical to manage the crucial aspects of resource consumption, litter and waste, crowding and congestion, transport, biodiversity, catering and food, water, air and noise pollution, sanitary facilities and environmental clean up which assess the overall environmental damage. However, at a national level, in the case of Ireland, the provision of environmental planning guidelines had traditionally been a non-mandatory requirement of Local Authorities while the provision of policies are legally required under the planning and development act 2000 and 2010. However incorporating environmental development strategies for event management in Local Authority policies is not a requirement in Local Authorities in Ireland. Nevertheless it would be beneficial for Local Authorities both in Ireland and also internationally to integrate environmental guidelines and policies within Local Authority planning processes for event management. This would be key in facilitating a transition towards environmental sustainability awareness in Local Authorities and event organisers. The provision of planning guidelines and policies for event management can provide valuable guidance on how to 
achieve environmental sustainability for event planning and management. Therefore an international and national events policy, with strategies and guidelines, which provides a good foundation for sustainability in the sector, may be a necessity for future environmental planning of event management.

\section{Methodology}

This up to date assessment involved extensive data collection and investigation into environmental event impacts and Local

\section{Table 1. Environmental Planning Guidelines for Festival and Event Management}

\section{Guidelines for Energy Conservation and Management \\ Reduce reliance on Fossil fuels \\ Mitigate greenhouse gas emissions \\ Use bio diesel \\ Rely on natural energy flows \\ Implement actions to reduce pollution of $\mathrm{Co} 2$ \\ emissions and greenhouse gases}

\section{Guidelines for Water Conservation and Management}

Reduce water consumption by implementing water management techniques- conservation \& recycling Monitor water quality and service

Implement low flow taps/dual flush toilets and waterless urinals

Protect usability of recycled water

\footnotetext{
Guidelines for Waste Management

Provide adequate waste separation methods

Monitor bin use

Reduce reuse recycle recover

No landfilling policy

Incentives for disposing of rubbish and separating waste

Eliminate the concept of waste through education and awareness

Limit car parking spaces

Use low emission vehicles

Host event close to public transport
}

\section{Guidelines for Catering and Food Stall \\ Management}

Source fresh local produce

Source fair trade products

Limitation of food packaging

No sale of plastic bottles

Sign up meal programme to reduce waste

Reduce food miles

Biodegradable and reusable supplies

\section{Guidelines for Managing People}

Educate event attendees of environmental event principles and communicate environmental awareness

Ensure public safety

Avoid overcrowding through ticketing

\section{Guidelines for Pollution Prevention (Light, Noise, Guidelines for Waste Water and Sewage Air, Water) \\ Reduce Toxic waste and chemicals \\ Avoid over consumption of resources \\ Use renewable energy \\ Monitor air and water quality \\ Implement transport management measures \\ Implement energy, water and waste management \\ measures

\author{
Treatment \\ Avoid chemicals for washing and hygiene \\ Implement alternative measures of sewage \\ treatment \\ Avoid the use of trucks to dispose of sewage \\ Ensure disposal of sewage waste is treated \\ Implement wastewater treatment system to infiltrate \\ back into soil
}

\section{Guidelines for Sanitary Facilities \\ Provide adequate portable/compost toilets \\ Provide waterless urinals \\ Use environmentally friendly soaps \\ Use rain water for showers (Weather permitted) \\ Use filtered wastewater for sanitary facilities}

\footnotetext{
Environmental Clean up

Assess environmental conditions before, during and

after event

Organise and environmental management team
}

\author{
Guidelines for Biodiversity and Landscape \\ protection and preservation \\ Protect biodiversity and sensitive environments \\ Preservation and protection of natural ecosystems \\ and heritage sites \\ Protect the quality of landscapes \\ Implement measures to reduce pollution and \\ environmental degradation \\ Promote environmental clean up programme \\ Rehabilitation and restoration of damaged \\ landscapes programme
}

Source: Adapted and modified from; (UNEP/UNWTO, 2005; Fáilte Ireland, 2007; DEFRA, 2007; Griffin et al, 2007; Raj \& Musarave. 2009: Jones. 2010: Fáilte Ireland. 2012: GSTC. 2013: EC. 2013) 
Authority planning provision for event management with a particular focus on Ireland as a case study. In particular the purpose of this current study was to assess the levels of planning provided for environmental impacts of events at a local level in Ireland. Local Authorities in Ireland have a legal remit under the planning and development act 2000 and 2010 to plan for the economic, socio-cultural and most importantly environmental development in their respective regions (DECLG, 2001; 2010). For this reason, a nationwide study of Local Authority planning and their relationship with environmental sustainability in event management was the primary focus of this study. Specifically the findings provided a valuable insight into the provision of environmental planning guidelines and policies for event management by Local Authorities. In order to conduct an examination into the level of sustainable environmental planning for event management in Ireland, an assessment framework "Local Authority provision of environmental planning guidelines" was developed. This framework incorporated the principle guidelines, tools and indicators from theory and international best practice, which enabled an assessment and examination of the specific level of Local Authority planning provided in Ireland.

\section{Method}

To assess the degree of environmental planning for event management by Local Authorities, a content analysis approach was utilised. The content analysis approach was the primary quantitative analysis tool as it represents quantification on a limited scale and is still anchored in the quantitative research paradigm. This approach may be considered a kind of reliability of the measures and a validation of eventual findings (Sellitz et al, 1967). Therefore quantification in content analysis tends to emphasise the procedures of analysis (Berg, 2007). This approach was considered ideal in examining the level of Local Authority planning provision for event management in Ireland as it allowed for a valuable cross representation of results in relation to the provision of environmental planning for event management by Local Authorities. In order to facilitate a constant comparison through the research process and to highlight variations between Local Authorities, data was inputted into a content analysis tool. The data from each category was then analysed and discussed in light of international literature. This particular approach

Table 2. Criteria for assessing LA provision of environmental planning guidelines and policies for Event Management

Local Authority generic planning guidelines for event management provided

Local Authority environmental planning guidelines

for event management provided

Local Authority policy provision in County

Development Plan (CDP)

Guidelines for resource consumption

Guidelines for energy consumption

Guidelines for energy conservation

Guidelines for water consumption

Guidelines for water conservation

Guidelines for water quality

Guidelines for drinking water

Guidelines for waste water

Guidelines for sewage treatment

Guidelines for litter and water management

Guidelines for catering and food safety

Guidelines for managing people

Guidelines for transport management

Guidelines for biodiversity conservation

Guidelines for disposal of food waste
Guidelines for pollution

Guidelines for reducing pollution

Guidelines for air pollution

Guidelines for noise

Guidelines for sanitary facilities

Guidelines for environmental clean-up and remedial works

Environmental Impact Assessment guidelines provided

Strategic Environmental Assessment guidelines provided

Sustainable Tourism Indicators

Environmental planning guidelines complaint with UNWTO 12 aims of sustainable tourism 2005

Environmental planning guidelines complaint with

DIT-ACHIEV Model of sustainable tourism management 2007

Environmental planning guidelines complaint with GSTC 2013

Environmental planning guidelines complaint with ETIS 2013

Source: adapted from (UNEP/UNWTO, 2005; GSTC, 2013; EC, 2013; Griffin et al, 2007) 
enriched the research in technical communication by identifying the frequency of themes and patterns. It can be applied to all kinds of written texts (Rose, Spinks \& Canhoto, 2015) therefore it was particularly useful in examining Local Authority planning processes, guidelines and policies. The variables assessed within the content analysis tool are shown below in Table 2 above.

Utilising the content analysis investigative tool to assess the above variables was a fitting way to accumulate data. The empirical assessment framework developed can enhance the reliability and validity of the findings (Boettger \& Palmer, 2010). The framework was informed and developed using principles from international best practice. The analysis centered on 31 criteria based on existing theory. The above criteria are incremental aspects of implementation, which ideally should be integrated within Local Authority planning processes for event management worldwide. In fact the environmental assessment planning criteria for event management can be applied to various countries. Yet, for the purpose of this study, the above criteria were used to assess the planning provisions of Local Authorities nationwide, in the Republic of Ireland. These variables are included and assessed within the content analysis tool to examine the environmental planning priorities in Local Authority planning processes (Table 4) and results are discussed in light of relevant literature.

\section{Sample}

In order to achieve nationwide perspectives on the levels of environmental planning for event management by Local Authorities, the authors identified and analysed 32 Local Authorities and City Councils in the Republic of Ireland using the above criteria. Local Authorities in Ireland are multi purpose bodies responsible for an extensive range of services in their respective regions. Each Local Authority exercises functions to varying degrees. For example, environmental protection is a key function, which incorporates waste collection, disposal and management, planning, litter prevention, air and water pollution control, building safety, water and sewerage planning and development and noise pollution control.
The current system of Local Government in the republic of Ireland comprises of 31 Local Authorities. There are 26 Local Authorities who are responsible for Local Government in twenty-four geographical Counties including the County of Dublin. County Dublin has 3 Local Authorities - South Dublin County Council, Dun Laoghaire-Rathdown County Council and Fingal County Council. There are 2 City and County Councils. They are responsible for Local Government in Limerick (Limerick City and County Council) and Waterford (Waterford City and County Council). Also there are three City Councils and they are responsible for Local Government in the cities of Dublin, Cork and Galway. A map of Local Authorities in the Republic of Ireland is shown below to illustrate the Local Authorities, which were assessed for the purpose of this study.

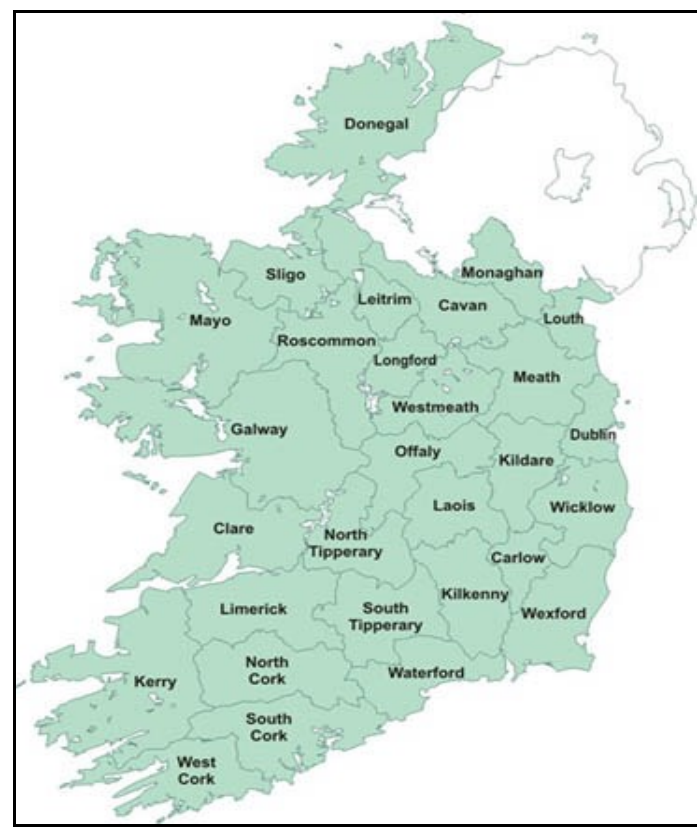

Figure 1. Map of Ireland

Source: Geological Survey of Ireland (GSI, 2010)

This study focuses on the 31 Local Authorities, however, one Local Authority "Tipperary" is separated into "Tipperary North" and "Tipperary South" Local Authorities. Therefore 32 Local Authorities are assessed in total giving a complete population of Local Authorities in the Republic of Ireland. 


\section{Data Analysis}

To facilitate the constant comparison of results throughout the research process and to highlight the variations and gaps between Local Authorities, data was inputted into the content analysis tool. This procedure allowed the authors to identify the level of environmental sustainability provided by Local Authorities for event management in Ireland. It also allowed the authors to investigate the relationship between environmental sustainability and effective policy and guideline implementation within Local Authorities. Considering Local Authorities have a legal remit under the Planning and Development Act 2000 and 2010 to plan for environmental developments, environmental planning provision within Local Authorities cannot be underestimated. This structured approach to analyse data facilitated the simplification of identifying the variation of results. This flexible and unobtrusive research approach was also used to determine the degree of recurring data throughout the research analysis process. As such, the analysis centered on a range of criteria based on existing theory and incorporated various models, tools and indicators developed by industry such as the UNWTO 12 Aims of sustainable tourism (2005), the DIT-ACHIEV model (2008), the ETIS (2013) and the GSTC (2013), as discussed previously. The comparison of results is discussed in the context of Irish legislation and current theory of international best practice. An example matrix of the content analysis framework is outlined below.

As can be seen below, the first and last letter of the County they represent abbreviates the Local Authorities displayed in the matrix. For example, "LK" abbreviates the first and last letter of County Limerick. Table 3 clearly highlights how Local Authorities varied on the categories assessed. For example, County Limerick had 58 events funded by Local Authorities in 2013 and had provided generic planning guidelines. Furthermore these guidelines incorporated environmental planning guidelines also, yet it had no policy provision within the County Development Plan for event management. The further comparison of results is discussed further in detail in the subsequent section.

\section{Results and Analysis}

The popularity of the festival and event industry in Ireland has increased at an expedient rate in previous years. It is now worth $€ 450 \mathrm{~m}$ in tourism revenue to the Irish economy and attracts over 300,000 overseas holidaymakers to Ireland each year (Ring, 2012; Fáilte Ireland, 2014). As well as this, the tourism industry in Ireland employs 180,000 people with 11,000 people in paid employment in festivals alone. While this has substantial economic benefits to host regions it also has negative consequences for the environment. Therefore requires solutions and a management approach to deal with and mitigate the environmental impacts of festival and event management.

The focus of this study was to provide a nationwide perspective on the levels of environmental planning for event management in Ireland. Under the Planning and Development Act 2000, 2001 and 2010 Local Authorities in Ireland are legally obliged and required to license events and provide supporting materials to ensure events are planned and organised in a way that is safe for event audiences and minimises environmental harm (DECLG, 2007; DECLG, 2014; Health Service Executive, 2014). In addition to this, national legislation requires planning to avoid, prevent and reduce negative harmful environmental impacts. However, to achieve environmental sustainability in planning for event management commands planning that considers environmental issues. This is necessary for the event industry in Ireland to be sustained into the future. As such, the provision and implementation of guidelines and policies by Local Authorities are needed at national and local level to manage this process and to facilitate environmental sustainability. To determine the level of environmental planning for event management by Local Authorities, every Local Authority in the Republic of Ireland was assessed using the criteria outlined in table 2. This determined which Local Authorities provided guidelines for environmental sustainability in event management. The results are illustrated in Table 4, below.

Analysis has highlighted the variation of results from Local Authority environmental planning 
Local authority provision of environmental planning guidelines for event management in Ireland.

provision under the many categories assessed. Analysis has clearly revealed an overall low level of planning provision for event management by Local Authorities in Ireland.
Therefore it seems that the Local Authority provision of environmental planning guidelines for event management have not fully been embraced by Local Authorities in Ireland.

Table 3. Example of Matrix from Content Analysis Framework

\begin{tabular}{|c|c|c|c|c|c|c|c|c|c|c|c|c|c|c|c|c|c|c|c|c|c|c|c|c|}
\hline \multicolumn{25}{|c|}{ Local Authority (LA) Provision of Environmental (env) Planning Guideline (EPG) } \\
\hline Criteria assessed within LA guidelines & CWCNCE & 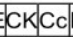 & & & $\mathrm{Dr}$ & $\mathrm{F}$ & & SCKE & EKK & KYYLS & SLLML & LKLLD & & & AMON & MNO & $\mathrm{R}$ & s & Ts & & WDV & WH & & WW \\
\hline LA events supported in 2013 & 33476 & 3422 & 41 & 22 & 1226 & 23 & \begin{tabular}{l|l}
622 \\
\end{tabular} & & $\begin{array}{ll}227 \\
\end{array}$ & \begin{tabular}{|l|l|}
46 & 2 \\
\end{tabular} & \begin{tabular}{|l|l|}
20 & 29
\end{tabular} & 5831 & 136 & & 112 & \begin{tabular}{|l|l|}
29 & 37
\end{tabular} & & & 731 & 28 & 56 & 36 & \begin{tabular}{|l|}
48 \\
\end{tabular} & 27 \\
\hline $\begin{array}{l}\text { LA Generic Planning guidelines } \\
\text { provided }\end{array}$ & & & & $x$ & & & $\mathrm{x}$ & & & & & $\mathrm{x}$ & $x$ & & & & & & & & & & & \\
\hline LA Env planning guidelines provided & & & & $\mathrm{x}$ & & & & & & & & $\mathrm{x}$ & $\mathrm{x}$ & & & & & & & & & & & \\
\hline LA Event Env policy Provision in CDP & & & & & & & & & & & & & & & & & & & & & & & & \\
\hline
\end{tabular}

Note: $\mathrm{x}$ - Local Authority provision made

Table 4. Local Authority Provisions of Environmental Planning Guidelines

\begin{tabular}{|c|c|c|c|c|c|c|c|c|c|c|c|c|c|c|c|c|c|c|c|c|c|c|c|}
\hline Local Aut & 1ority (L & (LA) $P$ & Prov & visio & on of & f En & nvirc & ronm & nental & I (env & iv) Plar & annin & $\mathrm{ng} \mathrm{C}$ & Guideli & line & (EF & PG) & & & & & & \\
\hline $\begin{array}{l}\text { Criteria assessed within LA } \\
\text { guidelines }\end{array}$ & & & & & & & $\mathrm{F}$ & & & & & & & & & & $\mathrm{R}$ & S & Ts & $\mathrm{Tn}$ & & & \\
\hline LA events supported in 2013 & 3347 & $\begin{array}{l}764 \\
64 \\
\end{array}$ & 422 & 4122 & 2212 & 226 & 236 & \begin{tabular}{l|l|l|}
62 & 29 \\
\end{tabular} & $\begin{array}{ll}32 & 27 \\
\end{array}$ & $\begin{array}{l}7462 \\
\end{array}$ & \begin{tabular}{l|l|l}
20 & 29 & 5 \\
\end{tabular} & \begin{tabular}{l|l}
58 & 31 \\
\end{tabular} & 136 & \begin{tabular}{|l|l|}
35 & 112 \\
\end{tabular} & 29 & 37 & 53 & 47 & 31 & 28 & 56 & 36 & \begin{tabular}{|l|l|}
48 & 27 \\
\end{tabular} \\
\hline LA Generic Planning guidelines & & & & \begin{tabular}{|l|l} 
& $x$ \\
\end{tabular} & $\mathrm{x}$ & & & $\mathrm{x}$ & & & & $\mathrm{x}$ & $x$ & & & & & & & & & & \\
\hline
\end{tabular}

LA Generic Planning guidelines provided

LA Env planning guidelines

provided

LA event env Policy provision in

CDP

Department of education event

code of practice guidelines

provided

Department of the environment

and local government code of

practice guidelines

Guidelines (G) for resource

consumption

G for energy consumption

$G$ for energy conservation

$G$ for water consumption

$G$ for water conservation

G for water quality

$G$ for drinking water

G for waste water

$\mathrm{G}$ for sewage treatment

$G$ for litter and waste

management

$G$ for managing people

$\mathrm{G}$ for transport management

$G$ for biodiversity conservation

G for catering and food safety

$G$ for disposal of food waste

$G$ for pollution

$G$ for reducing pollution

$G$ for Air pollution

$G$ for noise

$G$ for sanitary facilities

$G$ for environmental clean up

G for Environmental Impact

Assessment

G for Strategic Environmental

Assessment

Sustainable Tourism Indicators

G complaint with UNWTO 12

aims of sustainable tourism

G complaint with DIT-ACHIEV

Model

G complaint with GSTC

EG complaint with ETIS

Source: adapted from (UNEP/UNWTO, 2005; GSTC, 2007; EC, 2013; Griffin et al, 2007) 
However, environmental protection at events should be given priority in national legislative planning for event management given the economic significance of the event industry in Ireland.

Initially the research set out to examine how many, if any Local Authorities provided generic planning guidelines for event management. Generic planning guidelines outline the vast and significant areas, which require planning for event management. Research shows that just 4 out of 32 Local Authorities assessed provided generic planning guidelines for event management. More specifically the research set out to examine how many, if any Local Authorities provided environmental planning guidelines for event management. The development of environmental planning guidelines can provide event organisers and planners with practical advice and suggestions for sustainably planning events (NSW Government, 2011; DECLG, 2013). Likewise, they can encourage the incorporation of sustainability practices, which can contribute positively to the local economy and environmental preservation and generate many advantages (Muhanna, 2006; DEHLG, 2007). These advantages include cost savings, promoting positive reputations, raising awareness of environmental issues, influencing decision making and creating a competitive edge (UNEP, 2012). Environmental planning guidelines take into consideration the important sustainable principles and practices for ensuring minimal impact are caused to the environment. Such guidelines include elements of energy conservation, water conservation, water consumption, litter and waste management, managing people, transport management, catering and food safety, disposal of waste, pollution and noise to mention a few. Interestingly 3 Local Authorities provided guidelines for environmental planning within the generic planning guidelines. This low level of environmental guideline provision within Local Authorities was an interesting observation considering Local Authorities have a legal obligation to ensure events are organised causing minimal harm to the environment.
Subsequently, planning for the environment is given priority in national legislation through the development, provision and implementation of County Development Plans. CDP's are intended to provide a strategic framework and policy context for all planning decisions (Department of the Environment, Heritage and Local Government, 2007). The plans set out an overall strategy for the proper planning and sustainable development of the planning authorities region through the objectives included in the plan for a period of six years. They cover specific industries such as the tourism industry. However events are not a priority in any CDP in Ireland with the exception of Kilkenny who provides policies for events within the tourism policies. Therefore the significance and potential of the event sector has not been realised by Local Authorities in Ireland. Yet environmental planning policies and guidelines in national plans should be adopted and utilised by Local Authorities for event management in Ireland now that the event sector is an increasingly growing industry.

Upon analysing the provision of guidelines within Local Authorities and the provision of policies within CDP's, the environmental priorities provided within the guidelines for event management was assessed. This included indicators such as resource consumption, energy consumption, energy conservation, water consumption and water conservation. It has been noted that many resources are over used at events and cause resource depletion and toxicity endorsing unsafe environments and events (Berl \& De Meer, 2011). This mindless consumption of energy and water can produce undesirable amounts of $\mathrm{co} 2$ and greenhouse gases (Jones, 2009), which raises concern. Therefore planning for the management of resource consumption at events is a significant area in need of development since results revealed that no Local Authority provided guidelines for these specific areas. Yet it has been noted that resource efficiency is a key consideration in demonstrating awareness of sustainability in planning (DECLG, 2011; Jones, 2014). For this reason, these areas are substantial areas necessary in achieving sustainability in event management and are the areas where usage 
can be limited most. Moreover Tourism and events are major contributors to carbon emissions (McKercher, Prideaux \& Pang, 2003). Therefore managing the areas of energy and water can facilitate optimum resource recovery and minimal environmental degradation. This is necessary for the event lifecycle to effectively be sustained.

In addition to this, the provision of guidelines for water quality and drinking water was assessed. Hosting an event requires the provision of water in many areas such as sanitary facilities, food stalls and drinking points. For this reason, it is critical that the quality of water in drinking water, bathing water and ground water is maintained and monitored at events to sustain the quality and health of the environment while also protecting public health. Having analysed the provision of water quality and drinking water guidelines, results revealed that just 2 Local Authorities provided guidelines for ensuring water quality while 3 Local Authorities provided guidelines for drinking water at events. The provision of drinking water at events is essential for reasons of public health (DWI \& HPA, 2009). Therefore the importance of managing water at events is increasingly vital (Raj \& Musgrave, 2009; Case, 2012; Jones, 2014). In fact planning for water management at events is a critical element in sustainably planning for event management. Similarly, monitoring water quality is largely driven in legislation under the EU water framework directive (2000/60/EC). As such efforts for a water system free from contamination and pollution should be a key consideration in planning for event management. Moreover the responsibility of managing water quality falls at events falls to environmental health officers, Irish Water and Local Authority planners.

Furthermore, this paper examined which Local Authorities provided guidelines for litter and waste management. The three Local Authorities that recognised the importance of supplying environmental planning guidelines recognised the important of prioritizing litter and waste management guidelines. The accumulation of waste at events is inevitable at all events regardless of event size and scale (Malfas et al, 2004; Stettler, 2011). Therefore planning for waste generation in all areas of events is critical for event sustainability. Moreover waste management is effective in helping planners and policy makers consider options from waste avoidance or reduction through planning. In fact, waste management has been the responsibility of state governments and local government authorities for years (Giurco et al, 2015). Therefore the provision of policies and a sustainable and adaptive approach for waste management at events is essential. As such policy makers have embraced the adoption of a zero waste concept because it stimulates sustainable production and consumption and optimum recycling and resource recovery (Zaman, 2015), thus minimising negative consequences produced by waste and contributing towards sustainability in event management.

The event industry in Ireland attracts over 300,000 overseas holidaymakers each year (Ring, 2012; Fáilte Ireland, 2014). As a result of these crowds at events, impacts are generated, which has implications on the environment. For this reason planning for crowd congestion is a critical factor in sustainably planning for event management (Jones, 2014; Still, 2014). Additionally crowd control and crowd safety are significant factors to consider in planning for events. Therefore results were surprising in that only 3 Local Authorities provided guidelines for managing people at events. As such the need for crowd control measures are essential in ensuring that event audiences are kept safe throughout the conduct of the event as outlined in national legislation (Planning and Development Act 2000). Moreover crowd control can be achieved through effective management of human behaviour. Therefore crowd control should be a priority in Local Authority planning nationwide for event management.

Consequently, dealing with large crowds of people at events has a direct association with large-scale vehicle movement. Transport plays an important role in event management but has a huge impact on the environment (Harris 2003; Bowdin et al, 2012; Jones, 2014). Local Authorities have a key responsibility in transport management at events. They play a role in facilitating diversion routes, road 
closures and traffic signals (Callanan \& Keogan, 2003). Therefore the provision of guidelines for transport management in national legislation for event management is essential. Additionally transport planning is an integral part of traffic management therefore traffic planning is critical for success. However only 3 Local Authorities provide environmental planning guidelines for transport management.

Due to the unparalleled growth of events and the increased crowds of people attending events as well as traffic activities can critically affect biodiversity. As such, the need for guidelines for the protection of biodiversity conservation cannot be underestimated. However no Local Authority provided guidelines for biodiversity conservation therefore environmental planning within local government planning processes is not fully integrated to achieve sustainable planning for event management.

Additionally environmental planning guidelines were assessed to determine which Local Authorities provided guidelines for catering and food safety. Results revealed that just one Local Authority provided catering and food safety guidelines. This is surprising since nearly all events occurring throughout Ireland provide catering and food services (Jepson \& Clarke, 2015). In fact LA grant casual trading licenses to facilitate catering and food services at events (DECLG, 2007; Macken et al, 2013). Therefore it is astounding that just one Local Authority has prioritized catering and food safety into their planning guidelines. In addition to this, guidelines for the disposal of food waste were assessed. The disposal of food waste is essential and if not managed correctly can cause significant health and pollution consequences for the environment. Results illustrated that two Local Authorities provided guidelines for the disposal of food waste.

Subsequently, guidelines for pollution were examined which revealed two Local Authorities provided guidelines for pollution. Pollution can be generated almost everywhere at events and can cause physical and visual degradation to the environment (Elcome, 1999). Pollution can occur and be caused by not managing water, air, waste, food, sanitary facilities and vehicles
(Harssel et al, 2014). Pollution can affect public health therefore an area where pollution occurs requires monitoring and regulation by environmental health officers (Mcgranahan \& Murray, 2012). Moreover local government also has a role in managing pollution in certain areas as outlined in the water pollution act 1977. Furthermore guidelines for reducing pollution were examined and revealed no Local Authority provided guidelines for reducing pollution. However guidelines for noise pollution were provided by 3 LA. Noise pollution has become an inevitable part of modern civilization (Singh \& Deepak, 2013). Noise is an incremental element at events, which can impact the wider community; adversely impact general health and cause hostility toward the event therefore requires management. Under environmental noise regulations 2006 (SI NO 140) local government must ensure noise levels are kept at reasonable noise decibels.

Also, guidelines for sanitary facilities and environmental clean up were assessed. Results revealed that three LA provided guidelines for these elements. Sanitary facilities are crucial at events but must be monitored and maintained. In fact their maintenance and supervision has been identified as of paramount importance therefore planning for sanitary facilities in every Local Authority should be a priority for events. Moreover the environmental clean up after the event has ended is vital for the environment and the quality of the event.

Further to this, guidelines were also assessed to establish which Local Authorities provided guidelines for wastewater, sewage treatment, reducing pollution and air pollution. Interestingly no Local Authority provided guidelines for any of these event management elements. However the provision of guidelines for wastewater is critical for event management. In fact, part of national legislation outlines the construction or erection of pumping stations; treatment works, holding tanks or outfall facilities for wastewater is essential. Therefore outlining the importance of wastewater treatment plans. Additionally, national legislation require a plan for sewage discharge therefore guidelines should inevitably be provided for sewage treatment at events. 
Also, reducing pollution at events is a crucial step in facilitating sustainability in event management. In particular the areas of water, air, noise are vital areas where pollution and toxicity can occur therefore require management solutions to minimise the impacts.

Finally, this paper assessed which Local Authorities utilised the environmental impact assessment or the strategic environmental assessment in the guidelines for event management. Again results revealed that no Local Authority utilised either assessment techniques. This is surprising having already established the significance of these environmental assessment tools as measurements for improvements. Additionally, compliance with best practice standards such as the UNWTO 12 aims of sustainable tourism, the GSTC, the ETIS and the DIT-Achiev model were also assessed. Results exposed no Local Authority were compliant with any indicators of these tools. However the adoption and utilization of best practice standards in planning policies and guidelines would be beneficial in implementing sustainability in event management in Ireland while also mitigating negative environmental consequences. Moreover it can be a cost effective means of preventing irreversible impacts. Overall this study has found that national environmental planning provision of guidelines for event management has a low adoption rate in local authorities in Ireland. Therefore the potential of environment planning in event management has not been realised. As a result, adequate planning provision towards regulating and managing environmental impacts at events is needed.

\section{Conclusion and Discussion}

This paper has discussed from an international perspective the complex relationship between events and the environment and has explored the impacts and consequences created as a result of hosting an event. It has examined in the case study nationally, the extent of planning provided nationwide by Local Authorities in the Republic of Ireland for the environmental impacts of event management. To investigate the environmental planning provision by Local Authorities, a content analysis approach was employed. The results revealed an overall low level of environmental planning for event management in terms of planning policies and guidelines. Therefore Local Authority planning provision for the environmental impacts of event management has not been recognised in Ireland. As such, it seems Local Authorities are not taking adequate steps towards regulating and managing environmental impacts in their respective region. As a result of this, the complicated relationship between events and the environment now commands a planning and management approach initiated and implemented by Local Authorities. In fact, without an environmental planning approach, Local Authorities and event organisers may find it difficult to prevent inevitable and irreversible environmental impacts events may bring.

In terms of the provision of guidelines and policies within Local Authorities, guidelines and policies were found not to reflect or be compliant with sustainable tools such as the UNWTO/UNEP 12 aims of sustainable tourism. This is surprising considering the UNWTO together with the UNEP formulated a list of specific aims for sustainability in tourism (UNWTO/UNEP, 2005), to deliver a baseline for planning sustainably for tourism. In addition to this, guidelines and polices were found not to reflect or be compliant with sustainable indicators such as the DIT ACHIEV model, the GSTC, or the ETIS. In particular, even more surprising is the fact that no Local Authority reflected indicators from the DIT ACHIEV model, which was developed directly to apply to the case of Ireland for initiating sustainability in tourism and event management (Griffin et al, 2008). Similarly the GSTC, which is a widely accepted tool, developed based on already recognised criteria and approaches can be adopted to become more environmentally sustainable. However has not been integrated or incorporated in Local Authority provisions for event management. Considering the European Tourism Indicator system assists destinations to measure and monitor sustainability management processes, which enables them to benchmark progress and performance in the future (EC, 2013), it is startling to discover that indicators from this tool have not been applied to Local Authority event management processes. The application of indicators has been noted to act as an early warning system 
to initiate improved plans and management strategies (Griffin et al, 2012). As such it may be beneficial to facilitate sustainability in event management worldwide and in particular Ireland. Further to this, Local Authorities provided no guidelines for the use of regulatory tools for event management such as the EIA or the SEA. In addition, no policies existed in county development plans solely relating to event management. As such it may be beneficial for guidelines and policies to reflect international best practice standards when planning for environmental sustainability in event management. However adopting and utilising such best practice criteria can act as a guide to being more environmentally sustainable. Thus the development of proactive, comprehensive and robust planning tools such as guidelines and policies with the incorporation of sustainable indicators can effectively and efficiently facilitate environmental sustainability at events.

Moreover the growth of the event sector in Ireland (Ring, 2013; Fáilte Ireland, 2014) and the impacts this growth generates on the environment (Raj \& Musgrave, 2009; Case, 2013; Jones, 2014) calls for nationwide improvements in relation to planning sustainably for event management. As such, monitoring and measuring environmental impacts is crucial for the quality of the environment and the quality of an already successful event industry. This is essential for the event sector to be further developed and sustained. As a result the development of environmental policies and guidelines with sustainable indicators within legislative regulations within Local Authorities can act as a mechanism to facilitate environmental sustainability in event management. Thus advancing and sustaining the event sector and growing its potential in a sustainable and responsible way. Therefore to maximise environmental sustainability and minimise environmental impacts require a careful planning and management approach. Essentially, the achievement of environmental sustainability for event management relies upon government policies and guidelines reflecting a commitment to environmental quality and health. This will be crucial if the event sector is to be sustained, developed or advanced. In conclusion, there has been an overall lack of adoption and utilization of environmental policies in CDP's or event planning guidelines developed by local authorities. It is clear that more priority should be given to event planning and management at local level nationwide. This paper facilitates an opportunity for further research to investigate the absence of environmental planning guidelines for event management, which enables a longitudinal study.

\section{References}

Abaza, H., Bisset, R., \& Sadler, B. (2004) Environmental Impact Assessment and Strategic Environmental Assessment: Toward an integrated approach. Economics and trade brunch, UNEP. Geneva.

A Greener Festival (2012) Festival stats show steady progress on green issues but a rise in abandoned tents worries event organisers. Available from: www.agreenerfestival.com (accessed 22 July 2015).

Ali-Knight, J., Robertson, M., Fyall, A., \& Ladkin, A. (2008) International perspectives of festivals and events: Paradigms of Analysis. Elsevier, London.

BBC News (2010) Stampede at German Love Parade festival kills 19. Available from: www.bbc.com/news/world-Europe10751899 (accessed 12 July 2015).

Berg, Bruce L. (2007) Qualitative Research Methods for the Social Sciences. $6^{\text {th }}$ Ed. Allen \& Bacon, Boston, MA.

Berl, A., \& De Meer, H. (2011) An Energy Consumption Model for Energy Efficient Office Environments. Future Generation Computer Systems, 27(8), 1047-1055.

Bisset, R. (2011) Environmental Impact Assessments. Available from http://www .ilo.org/iloenc/part-vii/environmentalpolicy/item/745-environmental-impactassessments?tmpl=component\&print=1 (accessed 1 April 2015).

Bladen, C., Kennell, J., Abson, E., \& Wilde, N. (2012) Events Management: An Introduction. London: Routledge.

Bowdin, G., O'Toole, W., Allen, J., Harris, R., \& McDonnell, I. (2006) Events Management. $2^{\text {nd }}$ Edition. London: Routledge. 
Bowdin, G., Allen, J., Harris, R., O’Toole, W., \& McDonnell, I. (2012) Event Management, $3^{\text {rd }}$ edition. London and New York: Routledge.

Canter, L.W. (1999) Environmental Impact Assessment. CRC Press LLC. Available from ftp://ftp.energia.bme.hu/pub/hullgazd /Environmental\%20Engineers $\% 27 \% 20 \mathrm{Ha}$ ndbook/Ch02.pdf (accessed 1 April 2015).

Callanan, M., \& Keoghan, J.F. (2003) Local Government in Ireland - inside out. Available from: www.ipa.ie. (accessed 3 April 2015)

Carlsen, J. (2004) The Economics and Evaluation of Festivals and Events. In I. Yeoman, M. Robertson, J. Ali-Knight, S. Drumond, U. Mcmahon-Beattie. (eds), Festival and Event Management: An International Arts and Cultural Perspective, Butterworth-Heinemann, pp. 246-259.

Case, R. (2013) Events and the Environment. London: Routledge.

Ceron, J.P., \& Dubois, G. (2003) Tourism and Sustainable Development Indicators: The gap between theoretical demands and practical achievements. Current Issues in Tourism, 6(1), 54-75.

Choi, H., \& Sirakaya, E. (2005) Sustainability Indicators for Managing Community Tourism. Journal of Tourism Management, 27(6), 1274-1289.

Cibinskiene, A. (2012) impact evaluation of events as factors of city tourism competitiveness. Economics and Management 17(4) pp. 1333-1339.

Collins, A., Jones, C., \& Munday, M. (2009) Assessing the Environmental impacts of Mega Sports Events: Two options? Tourism Management, 30, 828-837.

Cornish, A. (2013) The potential of strategic environmental assessment to assist in mainstreaming biodiversity into decision making in Hong Kong. Available from: www.afdc.gov.hk/English/conversation/co m_bsap/bsap_bio_clearing_house/files/co mmon/20131212SEA.pdf (accessed 30 March 2015).

Damster, G., \& Tassiopoulos, D. (2005) Event Management: A professional and developmental approach, $2^{\text {nd }}$ edition. Juta and Company Itd.
David, L. (2009) Events and Tourism: An Environmental Approach and Impact Assessment. Journal of Tourism, Challenges and Trends, 2(2), 66-75.

David, L. (2009) Environmental Impacts of Events: In R. Raj \& J. Musgrave (Eds) Event Management and Sustainability, London: CAB International, pp. 66-75.

Davenport, J., \& Switalski, T.A. (2006) The Impacts of Transport related to Tourism and Leisure Activities. The Ecology of Transportation: Managing mobility for the environment. Environmental Pollution 10, 333-360.

Davenport, J., \& Davenport, J.L. (2006) The Impacts of Tourism and personal leisure transport on coastal environments: A Review. Estuarine Coastal and Shelf Science, 67(1-2), 280-292.

Dashper, K. (2015) Rural Tourism: an interactive perspective. Cambridge scholars publishing, UK.

Department of the Environment, Community and Local Government. (2007) Planning Acts/Bills. Available from: www. Environ .ie/en/DevelopmentHousing/PlanningDeve lopment/Planning/PlanningLegislationOverview/PlanningActs.

Department of the Environment, Community and Local Government. (2011) Our sustainable future: A framework for sustainable development for Ireland. Available from: www.environ.ie/en/ environment/SustainableDevelopment/pub licationsdocuments/FileDownLoad,30432, en.pdf.

Department of the Environment, Community and Local Government. (2012) Our Sustainable Future: A Framework for sustainable development for Ireland. (Dublin: DECLG).

Department of the Environment, Community and Local Government. (2013) Planning and Development Act (2010) (Dublin: DECLG).

Department of the Environment, Community and Local Government. (2013) Guidelines for Planning Authorities: An Bord Pleanála on carrying out Environmental Impact Assessments. Available from www.environ.ie (accessed 3 April 2015).

Department of the Environment Community and Local Government, (2014) Planning 
and Development Regulations 2001-2013 (unofficial consolidation) updated to 26 January 2015. Available from: www.environ.ie (accessed 26 March 2015).

Department of the Environment, Community and Local Government. (2014) Working group report on citizen engagement with local government. Available from: www.environ.ie (accessed 2 April 2015).

Department of the Environment, Community and Local Government. (2015) Statutory Instruments: Planning and Development (Amendment) Regulations 2015. Available from:

www.environ.ie/en/legislation/Developmen tandHousing/Planning/ (accessed 20 July 2015).

Department of the Environment, Heritage and Local Government (1997) Sustainable Development: A strategy for Ireland. (Dublin: DEHLG).

Department of the Environment, Heritage and Local Government (2007) Planning Guidelines: development plans: guidelines for planning authorities (Dublin: DEHLG).

Department of Transport Tourism And Sport (DTTAS). (2010) People, Place and Policy: growing tourism to 2025. Available from www.itic.ie/fileadmin/docs/peopleplace-policy-growing-tourism-2025.pdf

Department of the Environment, Community and Local Government. (2015) Planning and Development Regulations 2001-2013 (Unofficial consolidation) Updated January $262015 . \quad$ Available from: www.environ.ie/en/legislation//developmen t\&housing/planning/filedownload,32878.en .pdf.

DWI \& HPA. (2009) Drinking water safety: guidance to health and water professionals. Available from: dwi.defra.gov.uk/stakeholders/informationletters/2009/09-2009annex.pdf.

Elcome, D. (1999) The fragile environment: pollution and abuse. Nelson Thomes Itd. UK.

European Commission (2005) The SEA Manual: A source book on strategic environmental assessment of transport infrastructure plans and programmes. Available from: ec.europa.eu/environment /archives/eia/sea-studies-and-

reports/pdf/beacon-manual-en.pdf.

European Commission (2013) European Tourism Indicator System for sustainable destinations. Available from: ec.europa.eu/enterprise/sectors/tourism/su stainable-tourism/indicators/ documents _indicators/eu_toolkit_indicators_en.pdf.

European Commission (2014) European Tourism Indicator System: for sustainable management at destination level. Available from: www.ec.europa.eu/ enterprise/sectors/tourism/sustainable_tou rism/indicators/index_en.htm. (accessē 3 March 2015)

European Commission (2015) European Tourism Indicator System for sustainable destination management. Available from: ec.europa.eu/growth/sectors/tourism/susta inable/indicators.index_en.htm. (accessed 3 March 2015)

European Commission (2015) Strategic Environmental Assessment - SEA. Available from: ec.europa.eu/environment/ eis/SEA_legalcontext.htm.

EPA (2012) The provision and quality of drinking water in Ireland. A report for the year 2012. Available from: www.epa/pubs/reports/water/drinking\%20 water\%202012_web.pdf. (accessed 12 July 2015).

EPA (2014) Reducing toxic air pollutants. Available from: www.epa.gov/airquality /peg_caa/toxics.html (accessed 21 July 2015).

Evans, R. (2014) Decision Making in the Environmental Impact Assessment Process. Available from: dukespace .lib.duke.edu (accessed 3 April 2015).

Fáilte Ireland, (2007) Failte Ireland Festivals and Events Best Practice Guidelines. Available from: www.failteireland.ie (accessed 15 April 2015).

Fáilte Ireland. (2010) Visitor Attitude Survey 2010: Executive Summary. Available from www.failteireland.ie (accessed 30 March 2015).

Fáilte Ireland (2012) A guide to running green meetings and events. Available from: www.failteireland.ie (accessed 15 April 2015).

Fáilte Ireland, (2013) Festivals and Events to play a key role over the weekend. 
Available from: http://www.failteireland.ie /Utility/Media-Centre/As-bank-holiday

arrives,-tourism-industry-hopes-fo.aspx

(Accessed 8 March 2015).

Fáilte Ireland. (2014) As bank holiday arrives, tourism industry hopes for domestic bounce. Available from www.failteireland .ie (accessed 3 March 2015).

Fáilte Ireland. (2014) Shaun Quinn Addresses Oireachtas Committee. Available from http://www.failteireland.ie/News-

Features/News-Library/Shaun-Quinn,CEO-addresses OireachtasCommittee.aspx (accessed 3 March 2015).

Ferdinand, N., \& Kitchin, P.J. (2012) Event Management: An international approach. Sage Publications.

Finkel, R., McGillvray, D., \& McPherson, G. (2013) Research Themes for events. CABI UK.

Fischer, C. (2013) Municipal Waste Management in Germany. European Environmental Agency. Available from: www.eea.europa.eu. (accessed 2 July 2015).

Font, X., and Harris, C. (2004) Rethinking Standards from Green to Sustainable. Annals of Tourism Research, 31(4), 9861007.

Fredaline, L., Jago, L. \& Deery, M. (2003) The Development of a generic scale to measure the social impacts of events. Event Management, 8(1), 23-37.

Galligan, E., Mcgrath, M., \& Macken, J. (2013). Compulsory purchase and compensation in Ireland: law and practice. Bloomsberg publishing plc. Galway, Ireland.

Getz, D. (1997) Event Management and Event Tourism. Cognizant Communication Corporation.

Getz, D. (2006) Policy for Sustainable and Responsible Festivals and Events: Institutionalization of a new paradigm. Journal of Policy Research in Tourism, Leisure and Events, 1(1), 61-78.

Getz, D. (2008) Event Tourism: Definition, Evolution and Research. Tourism Management, 29, 403-428.

Giurco, D., Herrimen, J., Turner, A., Mason, L., White, S., Moore, S., \& Klostermann, F. (2015) Integrated resource planning for urban waste management. Available from: www.mdpi.com/2079-9276/4/1/3/pdf.

Global Sustainable Tourism Council (2013) Global Sustainable Tourism Criteria for destinations. Available from: www.gstcouncil.org/sustainable-tourismgstc-criteria/criteria-for-destinations-html (accessed 3 April 2015).

Goldblatt, J. (2010) Special Events: a new generation and the next frontier. John Wiley and Sons, New Jersey.

Goldblatt, S.D. (2012) The complete guide to greener meetings and events. John Wiley and Sons Inc.

Gonzalez, A., Fry, J., Hochstrasser, T., Scott, P., Carvill, P., \& Jones, M. (2011) A Methodological Approach to integrating strategic Environmental Assessment and Biodiversity impact assessment. Available from: www.ucd.ie/ibia/AGonzalez IBIAmethodology.pdf (accessed 5 April 2015).

Gossling, S., \& Hall, C.M. (2006) Tourism and Global Environmental Change. London: Routledge.

Gossling, S., Peeters, P., Hall, C.M., Ceron, J.P., Dubois, G., Lehman, L.V., \& Scott, D. (2011) Tourism and Water Use: Supply, Demand and Security. An International Review. Tourism Management, 33, 16-28.

Government of Western Australia (2009) Department of Health: guidelines for concerts, events and organised gatherings. Available from: www.public.health.wa.gov.au (accessed 20 April 2015).

Grames, E \& Vitcenda, M. (2012) Community Festivals-big benefits but risks too. University of Minessota. Available from: www.extension.umn.edu (accessed 21 March 2015).

Green, H., Hunter, C., Johnson, P., \& Thomas, P. (1992) The environmental impact assessment of tourism development. Perspective on Tourism Policy, pp. 29-47. Available from: www.cabdirect.org/ abstracts/19921896476.html.

Greenidge, K., \& Greenidge, N. (2011) Sustainable Tourism Development: The case of Barbados. Economic Review, 37(1/2), 85-125.

Griffin, K., \& Carty, J. (2006) Economic, environmental and social performance of 
the Irish Tourism Sector: Towards Sustainability. Tourism Research Centre DIT.

Griffin, K. (2007) Sustainable Tourism Indicators: Issues and challenges in the development of a sustainable tourism management model. Presentation at the Tourism and Hospitality Research in Ireland Conference, Dundalk, Ireland.

Gursoy, D., \& Kendall, K.W. (2006) Hosting Mega events: Modeling Locals Support. Annals of Tourism Research, 33(3), 603628.

Gursoy, D., Kim, K. and Uysal, M. (2004) Perceived impacts of festivals and special events by organiser: An extension and validation. Tourism Management 25, 171 181.

Hall, C.M (1992) Hallmark tourist events: impacts, management and planning. London: Belhaven press.

Hamil, S., Hassan, D., \& Lusted, J. (2012) Managing Sport; Social and Cultural Perspectives. Routledge.

Harssel, JV., Jackson, R.H., \& Hadma, LE. (2014) National Geographic visual geography of travel and tourism format. Cengage learning USA.

Holden, A. (2008) Environment and Tourism. Oxon, London: Routledge.

Holmes, K., Hughes, M., Mair, J., \& Carlsen, J. (2015) Events and Sustainability. Oxon, New York: Routledge.

HSE (2014) Health service executive requirements and guidance for outdoor crowd events. Available from: http://www.hse.ie/eng/services/Publication s/corporate/Emergency Management/cro wdeents.pdf (Accessed 21 March 2015).

Hugo, G. (1996) Environmental concerns and international migration. International Migration Review, 30(1), 105-131.

International Festival and Event Association (2009) The business of International events. Available from: www.ifea.com (accessed 12 July 2015).

IRO (2013) Irish Regions office. Available from www.iro.ie (accessed 10 April 2015).

Department of Environment, Community and Local Government, (2010) Planning Review Report. Available from: www.environ.ie (accessed 1 January 2015).
Janeczko, B., Mules, T. and Ritchie, B. (2002) Estimating the economic impacts of festivals and events: A resource guide. Available from: www.crctourism.com.au (accessed 12 March 2015).

Jeong, G., \& Faulkner, B., (1996) Resident Perceptions of Mega Event Impacts: The Taejon International Exposition Case. Festival Management and Event Tourism, 4, pp. 2-11.

Jepson, A., \& Clarke, A. (2015) Exploring Community Festivals and Events. Oxon and New York: Routledge.

Jones, M. (2009) Sustainable Event Management: A practical guide. Earthscan, London.

Jones, C. (2012) Events and Festivals: Fit for the Future. Event Management, 16(2), 107-118.

Jones, S. (2008) political ecology and land degradation: how does the land lie 21 years after Blaikie and Brookfields land degradation and society. Geography Compass, 3(2), 671-694.

Jones, M. (2010) Sustainable event management: A practical Guide. Second edition. Earthscan, London.

Jones, R., Pilgrim, A., Thompson, G., \& Mcgregor, C. (2008) Assessing the impacts of special events: examination of nine special events in Western Australia with particular reference to the approval process and identification of potential environmental impacts. Western Australia, Corporate Research Centre for sustainable tourism. Available from: www.sustainabletourismonline.com.

Jones, C., Baker, M., Carter, J., Jay, S., Short, M., 7 Wood, c. (2013) Strategic Environmental Assessment and Land Use planning: An international Evaluation. Earthscan, UK.

Jones, M. (2014) Sustainable Event Management: A practical guide. Earthscan, London.

Kaval, P. (2011) Measuring and valuing environmental impacts: A systematic Review of existing methodologies. Available at: http://www.nbs.net/wpcontent/uploads/NBS-Systematic-ReviewImpacts.pdf

Kim, H., Borges, M.C., \& Chon, J. (2006) Impacts of Environmental Values on 
Tourism Motivation: The case of FICA, Brazil. Tourism Management, 27, 957967.

Laing, J., \& Frost, W. (2010) How green was my festival. Exploring challenges and opportunities associated with staging green events. International Journal of Hospitality Management, 2(2), 261-267.

Lee, N., \& Walsh, F. (2012) Strategic Environmental Assessment: An Overview. Project Appraisal, 7(3), 126-146.

Lemos, C., Fischer, T., \& Souza, M.P (2012) Strategic Environmental Assessment in Tourism Planning - extent of application and quality of documentation. Environmental Impact Assessment, 35, 1-10.

Li, J.C. (2008) Environmental impact assessments in developing countries: an opportunity for greater environmental security. Working paper No 4. Available from: fess-global.org/WorkingPapers /EIA.pdf.

Lozano-Oyola., M., Blancas, F.J., Gonzalez, M., \& Caballero, R. (2012) Sustainable Tourism Indicators as planning tools in cultural destinations. Ecological Indicators, 18, 659-675.

Macintosh, A. (2010) Best Practice Environmental Impact Assessment: A model framework for Australia. Australian Journal of Public Administration, 69(4), 401-417.

Maguire, J. (2013) Social Sciences in Sport. Human Kinetics, U.S.A.

Malfas, M., Theodoraki, E., \& Houlihan, B. (2004) Impacts of the Olympic games as mega events. Proceedings of the ICE. Municipal Engineer, 157(1), 209-220.

Mallen, C., \& Adams, L.J. (2010) Environmental sustainability education and the sport management academy. Quarterly Greek review of Oikonomia \& Athilitismos, 10(1), 8-22.

Mallen, C., \& Adams, L.J. (2013) Event Management in Sport: Recreation and Tourism: Theoretical and Practical Dimensions. Butterworth Heinemann, UK.

McGranahan, G., \& Murray, F. (2012) Air pollution and health in rapidly developing countries. Earthscan, UK.

McKercher, B., Prideaux, B., \& Pang, S. (2013) Attitudes of Tourism Students to the environment and climate change. Asia
Pacific Journal of Tourism Research, 18(12), 108-143.

Miller, G., (2001) The development of Indicators for sustainable Tourism: Results of Delphi Survey of Tourism Research. Tourism Management, 22(3), 351-362.

Miller, G., \& Twinning-Ward, L. (2005) Monitoring for a sustainable Tourism Transition: the challenges of developing and using indicators. $\mathrm{CABI}$ International: UK.

Moore, T. (2014). The Guardian: Festival Season: How to enhance sustainable behavior among campers. Available from: www.theguardian.com/sustainablebusiness/estival-season-waste-emissiontransport-sustainable-behaviour. (accessed 18 July 2015).

Morrissey, M., Flanagan, S., \& Griffin, K. (2010) The DIT ACHIEV model of sustainable tourism management: the trails and tribulations of indicator models. In Phillips, R. \& Budruk, M. (2010) Quality of life and community indicators for parks, recreation and tourism management, Springer, USA, pp. 201-229.

Mowforth, M., \& Munt, I. (2009) Tourism and Sustainability: Development of a new tourism in the third world. $3^{\text {rd }}$ edition. London: Routledge.

Muhanna, E. (2006) Sustainable Tourism Development and environmental management for developing countries. Problems and Perspectives in Management, 4(2),.14-30.

Murphy, P.E, \& Price, G.G. (2005) Tourism and Sustainable Development: In Theobald. W.F (Ed). Global Tourism. $3^{\text {rd }}$ ed. Butterworth Heinemann. Burlington MA. PP 167-193.

NSW (New South Wales) Government. (2011) Developing a Council Community Events Policy. A toolkit for NSW Councils. Premier and Cabinet division of local Government. NSW.

O' Brien, D., \& Gardiner, S. (2006) Creating Sustainable Mega Event Impacts: Networking and Relationship Development through Pre-event training. Sport Management Reviews, 9, 25-48.

OECD (2003) Towards sustainable development indicators to measure 
progress. Available from: www.oecd.org /site/worldforum/33703694.pdf.

OECD (2006) Apply strategic environmental assessment: good practice guidelines for development. Available from: www.oecd.org/dac/environmentaldevelopment/37353158.pdf (accessed 3 April 2015).

OECD (2008) Key environmental indicators. Available from: http://www.oecd.org/ env/indicators-modelling-outlooks/ 37551205.pdf (accessed 3 April 2015).

Omer, A.M. (2008) Green Energy and the Environment: Renewable and Sustainable Energy Reviews, 12(7), 1789-1821.

Omer, A.M. (2010) Water Resource Management and sustainable development in Sudan. International Journal of Water Resource and Environmental Engineering, 2(8), 190-207.

Omoregie, E. (2012) The impacts of event tourism on host communities: Case: the city of Pietarsaari. Available from: www.theseus.fi accessed (20 December 2014).

Partadario, MR. (2003) Strategic Impact Assessment for spatial planningMethodological guidance for application in Portugal. Final Report of a project, FCTUNL.

Partadario, MR. (2007) Strategic Environmental Assessment: Good practice guide. Portuguese Environment Agency.

Partadario, MR. (2012) Strategic Environmental Assessment: better practice guide Methodological guidance for strategic thinking. SEA: Lisbon.

Peats Ridge Festival (2014) Peats Ridge festival in Australia. Available from: peatsridefestival.com.au (accessed 12 July, 2015).

Pernecky, T., \& Luck, M. (2013) Events, Society and Sustainability: Critical and Contemporary Approaches. London Routledge.

Quinn, B. (2009) Festivals, Events and Tourism: In Jamal, T., \& Robinson, M. (eds) The Sage Handbook of Tourism Studies. London: Sage, pp. 483-503.

Quinn, B. (2013) Key concepts in Event Management. London: Sage.
Raj, R. and Musgrave, J. (2009) Event Management and Sustainability. CABI, Oxfordshire, UK.

Rajaonson, J., \& Tanguay, G.A. (2012) Strategy for selecting sustainable tourism indicators for the Gaspésie and lles de la Madelne Regions. Innovation and Sustainable Tourism. Pp. 77-84.

Reed, MS., Fraser, EDG., \& Dougill, A. (2006) An adaptive learning process for developing and applying sustainability indicators with local communities. Ecological Economics, 59, 406-418.

Ring., M. (2013) Minister of state for Tourism and Sport: "Doing business for Irish Tourism". Retrieved from: http://www. failteireland.ie/News-Features/News Library/Doing-the-Business-for-IrishTourism.aspx (accessed 13 March 2015).

Richards, G., 7 Palmer, R. (2010) Eventful Cities: Cultural Management and Urban Revitalisation. Butterworth-Heinemann. UK.

Ritchie, J.R.B. (1984) Assessing the impact of hallmark events: conceptual research issues. Journal of Travel Research, 23(1), $2-11$.

Ritchie, J.R.B., \& Smith, B.H. (1991) the impact of a mega event on host region awareness: A longitudinal study. Journal of Travel Research, 31(1), 3-10.

Rizal, P., \& Asoken, R. (2014) emerging environmental issues with the development of tourism industry in India: A study. International Journal of Development Research, 4(5), 995-999.

Robertson, W., Stanfield, G., Howard, G., \& Bartram, J. (2003) Monitoring the quality of drinking water during storage and distribution. In Dufour, A., Snozzi, M., Koster, W., Bartram, L., Ronchi, E., Fewtrell, L. (eds). Assessing microbial safety of drinking water: improving approach and methods. IWA Publishing: London.

Robinson, P., Heitmann, S., \& Dieke, P. (2011) Research Themes for Tourism. CABI, Wallingford, UK.

Rockwerchter Festival (2015) Rock Werchter Festival 2015. Available from: www.rockwerchter.be (accessed 20 July 2015). 
Roper, T. (2006) Producing Environmentally Sustainable Olympic Games and green major public events. Global Urban Development, 2(1).

Roskilde Environmental Group (2014) Environmental handbook of festivals and outdoor events. The Case of The Roskilde festival Denmark. Available from: www.miljohandboken.no (accessed 12 July 2015).

Saayman, M. (2012) Introduction to Sport Tourism and Event Management. Sun Press.

Scott, C. (2008) Strategic Environmental Assessment (SEA) and good governance: Tryst and Tension?. The international Journal of Public Participation, 2(2), 5-24.

Sellitz, C., Jahoda, Deutsch, M. and Cook, S.W. (1967) Research methods in social relations. Riveharat \& Winston, New York.

Shanka, T., and Alimiyo, G. (2004) Motivations to visit Events/Festivals: An exploratory investigation. Western Australia.

Shipway, S. \& Fyall, A. (2013) International Sports Events: Impacts, Experiences and Identities. Routledge. Oxon.

Shone, A., \& Parry, B. (2004) Successful Event Management: A Practical Handbook. Second edition. Cengage Learning EMEA.

Singh, N.U., \& Deepak, S. (2013) Study of noise pollution levels during a Hindu festival in Dhar Town, MP, India. Research Journal of Chemical Sciences, 3(12), 7175.

Small, K., Edwards, D., \& Sheridan, L. (2005) A flexible framework for evaluating the sociocultural impacts of a small festival. International Journal of Event Management Research, 1(1), 66-77.

Sorupia, E. (2005) Rethinking the role of Transport in Tourism: Proceedings of the Eastern Asia society for transportation studies, 5, 1767-1777.

Spaziante, A., \& Murano, C. (2008) Strategic Environment Assessment in rural development policy: A survey in the ex ante evaluation phase in Italy. ESRA 2008, Liverpool.

Stettler, SL. (2011) Sustainable Event Management of music festivals: An event organisers perspective. A master of science submitted to the Portland state university.
Stone, P., \& Sharpley, R. (2011) Socio-cultural impacts of events: meanings, authorized transgression and social capital. In $\mathrm{S}$. Page and J. Connell (eds.) The Routledge Handbook of Events. London, Routledge.

Tanguay, G.A., Rajaonson, J., \& Therrien, M.C. (2011) Sustainable Tourism Indicators: selection criteria for policy implementation and scientific recognition. CIRANOScientific Publication No. 2011 pp. 5-60.

Tassiopoulos, D. (2005) Event Management: A professional and developmental approach. $2^{\text {nd }}$ Edition: Juta Academics Itd.

The guardian (2010) Festival goers killed in stampede at Love parade in Germany. Available from: www.theguardian.com/ world/2010/Jul/24/love-parade-festivaltunnel-stampede (accessed 21 July 2015).

Therivel, R., \& Partadario, MR. (1996) The practice of strategic environmental assessment. Earthscan, London.

Therivel, R. (2012) Strategic Environmental Assessment in Activities. Earthscan. UK \& USA.

Tourism Ireland. (2014) New Tourism Ireland Research shows strong potential for growth from China. Available from: www.tourismireland.com (accessed 28 March 2015).

UNCCD (2014) United Nations Convention to Combat Diversification: Land Degradation Neutrality: Resilience at Local, National and Regional levels. Available from: www.unccd.int/lists/SiteDocumentLibrary/ Publications/Land_Degrad_Nautrality_E_ Web.pdf. (accessed 18 July 2015).

UNEP (2005) Making Tourism More Sustainable: A guide for policy makers. Available from: www.unep.fr/shared/ publication/pdf/DTIx0592xPA-

TourismpolicyEN.pdf

UNEP (2011) Sick Water? The central role of wastewater management in sustainable development: $A$ rapid response assessment. Available from: www.unep. org/pdf/SickWater_screen.pdf (accessed 11 July 2015).

UNEP/UNWTO (2005) 12 Aims of Sustainable Tourism. Available from: www.unep.org (accessed 2 April 2015).

UNEP (United Nations Environmental Program) (2012) Sustainable United Nations: Sustainable events guide: Give your large 
event a small footprint. Available from: worldcongress2012.iclei.org/fileadmin/tem plates/WC2012/Documents/presentations/ B3 Sustainable_Events_Guide.pdf (Accessed 8 January 2015).

UNWTO (2004) Indicators of sustainable development for tourism destinations: $A$ guidebook. UNWTO: Madrid, Spain.

UNWTO (2004) The guidebook on indicators of sustainable development for tourism destinations. UNWTO: Madrid, Spain.

UNWTO (2015) Over 1.1billion tourist travelled abroad in 2014. Available from: media.unwto.or/press-resease/2015-01-

27/over-11-billion-tourists-travelledabroad-2014 (accessed 24 July 2015).

Van der Wagen, L., \& White, L. (2010) Event Management: For Tourism, Culture, Business and Sporting Events. $4^{\text {th }}$ Edition. Pearson, Australia.

Vernon, J., Essex, S., Pinder, D., \& Curry, K. (2005) Collaborative policymaking: local sustainable projects. Annals of Tourism Research, 23(2), 325-345.

Wale, D., Robinson, P., \& Dickenson, G. (2010) Events Management. CAB International, UK \& USA.

Wall, G., \& Mathieson, A. (2006) Tourism: Change, Impacts and Opportunities. Pearson Education Limited.

Wambach, K., Aicher, T.J., Riordan, J., PauleKoba, A.L., \& Newland, B. (2015) Sport Facility and Event Management. Jones \& Bartlett, Burlington, MA.

Wathern, P. (2013) Environmental Impact Assessment: Theory and Practice. Routledge.

Weaver, D. (2006) Sustainable Tourism: Theory and practice. Butterworth Heinemann, Oxford.

Wood, C., \& Djeddour, M. (1992) Strategic Environmental Assessment: Environmental Assessment of policies, plans and programmes. Impact Assessment Bulletin, 10(1), 3-21.
Wood, E. (2006) Measuring the Social Impacts of Local Authority Events: A scale to quantify civic pride. International Journal of Non-Profit and Voluntary sector marketing, 11, 165-179.

Wood, E. (2009) An Impact Evaluation Framework: Local Government Community Festivals. Event Management, 12, 1-17.

World Health Organisation (2004) Guidelines for drinking water quality. $3^{\text {rd }}$ ed, Vol 1: Recommendations. Geneva.

World Health Organisation (2014) Progress on sanitation and drinking water 2013 update. Available from: apps.who.int/iris/bitstream/10665/81245/1/ 9789241505390_eng.pdf (accessed 14 July 2015).

WTO \& Ministry of Tourism and the Environment (2007) Sustainable Tourism Indicators and Destination Management. Montenegro. Available from: sdt.unwto.org/sites/all/files/pdf/finrep.pdf

Xiao, H. (2014) Contemporary perspective on China tourism. Routledge, New York.

Yeoman, I., Robertson, M., Ali-Knight, J., Drummond, S., \& McMahon-Beattie, U., (2004) Festival and Event Management: An international Arts and Cultural Perspective. Butterworth-Heinemann, Oxford.

Yeoman, I., Robertson, M., McMahon-Beattie, U., Baker, E., \& Smith, K.A. (2015) The Future of Events and Festivals. London, Routledge.

Zaman, AU. (2015) measuring waste management performance using the zero waste index. The case of Adelaide, Australia. Journal of Cleaner Production, $66,407-419$. 